\title{
Zarys polityki wielojęzyczności Królestwa Hiszpanii
}

\begin{abstract}
An outline of the multilingual policy of the Kingdom of Spain). This paper concerns the situation of multilingualism in Spain, with particular emphasis on its legal regulations. Nowadays around half of the Spanish population live in bilingual or multilingual areas. The situation of the country's multilingualism is reflected in relevant legal acts and in the Spanish Constitution itself. The reality of a multilingual society is included in the legal system and is reflected in all spheres of social life. The process of regional language recovery in the Iberian Peninsula is also often associated with the demands of regional independence (e.g. in Catalonia or the Basque Country). The concept of multilingualism thus becomes a hostage of itself and seems to undermine the principle of pluralism. Is the Spanish model effective and what are the principles it is based on?
\end{abstract}

\begin{abstract}
Abstrakt. Niniejszy artykuł dotyczy sytuacji wielojęzyczności w Hiszpanii, ze szczególnym uwzględnieniem regulacji prawnych jej dotyczących. Obecnie na terytorium Królestwa Hiszpanii około połowa mieszkańców Hiszpanii zamieszkuje obszary dwu- lub wielojęzyczne. Sytuacja wielojęzyczności kraju odzwierciedlona jest w stosownych aktach prawnych oraz w samej konstytucji Królestwa. Rzeczywistość wielojęzycznego społeczeństwa ujęta jest w systemie prawnym oraz odzwierciedla się we wszystkich sferach życia społecznego. Proces rewindykacji języków regionalnych na Półwyspie Iberyjskim jest też często związany z postulatami niezawisłości regionów (np. w Katalonii lub w Kraju Basków). Koncepcja wielojęzyczności staje się zatem zakładniczką samej siebie i wydaje się podminowywać odgórną zasadę pluralizmu. Czy model hiszpański jest skuteczny i jakie stoją za nim przesłania?
\end{abstract}


Esta conciencia de herederos de un legado intrínsecamente valioso, pero cuyo valor aumenta, paradójicamente, conforme se multiplican los beneficiarios, puede ser, agotados los argumentos que apelan a la historia común, la razón últiima y decisiva para defender esa unidad del idioma que todos deseamos mantener.

[Ta świadomość spadkobierców tak cennej spuścizny, której wartość wzrasta, paradoksalnie, wraz ze wzrostem liczby tych, którzy z niej korzystają, po wyczerpaniu argumentów odwołujących się do wspólnej historii, może się okazać ostatecznym i decydującym powodem do obrony tej jedności języka, którą wszyscy chcemy utrzymać.] ${ }^{1}$

Emilio Lorenzo, «Utrum lingua an loquentes»?: sobre las presuntas dolencias y carencias de nuestro idioma, w: El español en la encrucijada, Madrid, 1999.

\section{Wstęp}

Uwzględnienie różnorodności językowej w społeczeństwach postmodernistycznych jest jednym z najważniejszych i najtrudniejszych zadań współczesnej polityki językowej, ponieważ tzw. państwa zachodnie nadal w dużym stopniu opierają się na pojmowaniu tożsamości narodowej opartej między innymi na jednym, wybranym języku. Kwestia Królestwa Hiszpanii jest szczególnie interesująca, ponieważ jest ono domem dla bardzo znaczących mniejszości językowych. W rzeczywistości językiem ojczystym około 25 procent Hiszpanów nie jest oficjalny język państwa, czyli kastylijski².

Hiszpania często postrzegana jest na zewnątrz jako kraj jednojęzyczny. Być może wynika to z pewnej tendencji części rządu centralnego, by odzwierciedlić państwo w mediach i polityce jako jednojęzyczne - taki przekaz bowiem utrwala odbiór Hiszpanii jako państwa zjednoczonego. Co ciekawe, Narodowy Instytut Statystyczny Hiszpanii (Instituto Nacional de Estadística) nie publikuje danych językowych na swojej stronie internetowej, chociaż od 1986 r. kwestionariusze spisu powszechnego zawierają pytania dotyczące używania języka.

Jednocześnie, nawet obecnie, ponad cztery dekady po zakończeniu reżimu dyktatorskiego generała Francisca Franco, skutki jego centralizującej polityki narodowościowej są wciąż żywe w postawach językowych mniejszości w Hiszpanii. Postawa obywatelska zakładająca, że język (regionalny) jest jednoczącym symbolem tożsamości regionalnej, aby stawić opór hiszpańskiej hegemonii, w dalszym ciągu jest aktualna i postrzegana jako słuszna. Dlatego też można zauważyć narastanie ,nacjonalistycznej gorliwości" pośród rosnącej stopniowo liczby obywateli Hiszpanii posługujących się na co dzień językiem katalońskim, baskijskim czy galicyjskim. Pomimo powszechnie podziwianego ustroju konstytucyjnego (Estado de las Autonomías), Hiszpania nadal zmaga się, w pewnych aspektach, z problemem mniejszości narodowych.

1 Tłumaczenie autora.

2 zob. https://www.ethnologue.com/country/ES/status [15.02.2018] 
Współistnienie wielu języków rzuca wyzwanie polityce wielokulturowej, podobnie jak różnorodność religijna i kulturowa. Demokratyczne zarządzanie różnicami językowymi jest jednym z najtrudniejszych zadań obecnej polityki wielokulturowej, ponieważ - jak wspomniano wcześniej - państwa zachodnie nadal pozostają w dużej mierze zależne od tożsamości ukształtowanych przez języki (Ruiz Vieytez 2007: 1).

\section{Hiszpania dwu- i wielojęzyczna}

Używanie dwóch języków może oznaczać, że dana osoba wybiera jeden lub drugi język w zależności od sytuacji komunikacyjnej, ale może również oznaczać, że posługuje się ona dwoma językami podczas tej samej sytuacji komunikacyjnej, co stanowi przykład zjawisk code-switching oraz code-mixing.

Sytuacja dwujęzyczności (lub w niektórych przypadkach wielojęzyczności) w wielu regionach Hiszpanii jest wynikiem historii polityczno-społecznej Półwyspu Iberyjskiego. Od XVI wieku język kastylijski ${ }^{3}$ zyskiwał na popularności jako język dominujący nad innymi językami Półwyspu. Przez wieki języki regionalne współistniały z kastylijskim w relacji diglosji, będąc stygmatyzowanymi językami ludności wiejskiej i niższych warstw społecznych (z wyjątkiem katalońskiego). Długie współistnienie w tej relacji hierarchicznej miało konsekwencje dla postaw mówców, użycia oraz struktury języków pozostających w kontakcie.

Użytkownicy stygmatyzowanego języka często mają tendencję do inkorporowania elementów prestiżowego języka dominującego - w przypadku Hiszpanii kastylijskiego. Dotyczy to nie tylko terminów nieistniejących w ich własnym języku, ale także tych, które mają swoje odpowiedniki. W ten sposób pierwszymi obcymi elementami, które wchodzą w skład języka, są jednostki leksykalne. Jeśli występuje silny nacisk ze strony języka pożyczającego i jeśli kontakt między językami trwa długo, wpływ języka dominującego przejawia się także na innych poziomach języka, np. na poziomie morfologicznym czy składniowym (zob. Thomason i Kaufman 1988: 37-39). Jednak w społeczeństwach dwujęzycznych ten wpływ nie jest jednokierunkowy; język zdominowany uobecnia się na pewnych poziomach w języku dominującym: najpierw na poziomie fonetyczno-fonologicznym, a jeśli kontakt trwa, także na pozostałych . Wynikiem jest pojawienie się mieszanych lub hybrydowych odmian (Gugenberger 2008: 31), zajmujących miejsce w continuum językowym miedzy kastylijskim i językami regionalnymi, czasami zbliżając się bardziej do kastylijskiego, innym razem bardziej do języka regionalnego.

Zjawisko interferencji występujące w sytuacjach kontaktu językowego obejmuje wszystkie podsystemy języka (zob. dalej punkt 2.2.). Mówiąc o continuum językowym,

$3 \quad$ Wg Diccionario panhispánico de dudas nazwy castellano (kastylijski) oraz español (hiszpański) dla oznaczania oficjalnego języka Królestwa Hiszpanii oraz wielu krajów Ameryki Łacińskiej są równoznaczne. Zob.: http://lema.rae.es/dpd/srv/search?id=xR5izpBqMD61osuofd [25.02.2018] 
mam na myśli całą gamę odmian na osi język kastylijski-języki regionalne. Wszakże rzeczywistość językowa Hiszpanii potwierdza fakt, że nawet gdy dana osoba posługuje się tylko jednym kodem językowym, nie mówi w „, języku neutralnym”, bez żadnych naleciałości regionalnych. Obecność cechy regionalnych zależy od różnych czynników (np. stopień formalności wydarzenia komunikacyjnego itp.), ale znalezienie ,neutralnego" użytkownika „czystego” języka będzie trudne.

\subsection{Code-switching}

W wielu regionach Hiszpanii używanie dwóch języków dla mieszkańców jest codzienną rutyną. W Katalonii 56,7\% populacji używa języka hiszpańskiego i katalońskiego w interakcjach z kolegami z pracy ${ }^{4}$. W Galicji 37,2\% populacji wskazuje galicyjski i hiszpański jako dwa podstawowe języki codziennej komunikacji (Gugenberger 2008: 31).

W przypadku Kraju Basków język baskijski, znacznie różniący się od hiszpańskiego, zajmuje pozycję mniejszościową, gdyż wg danych z 2016 roku $33,9 \%$ ludności Baskijskiej Wspólnoty Autonomicznej ${ }^{6}$ (País Vasco) w wieku 16 lat i więcej to osoby baskijskojęzyczne; $19,1 \%$ to bierni użytkownicy języka baskijskiego, a 47\% ludności posługuje się wyłącznie kastylijskim. Ponad połowa mówców w wieku 16-24 lat to osoby dwujęzyczne z przewagą użytkowników kastylijskiego $(55,7 \%)$. Na terytorium Kraju Basków 30,6\% osób w wieku 16 lat i więcej używa języka baskijskiego w mniejszym lub większym stopniu, przy czym $20,5 \%$ intensywnie korzysta z baskijskiego, to znaczy używa go na co dzień w takim samym stopniu lub częściej niż kastylijskiego, a z kolei 10,1\% używa języka baskijskiego, ale rzadziej niż kastylijskiego. Pozostali $(69,4 \%)$ używają języka hiszpańskiego zawsze lub prawie zawsze.

Ze względu na represyjną politykę hiszpańskiego rządu przez większą część XX wieku, język baskijski tracił wpływ i obecność w przestrzeni publicznej. Wraz z uchwaleniem ustawy o autonomii w 1979 r. jednym ze zobowiązań nowych baskijskich instytucji autonomicznych był proces normalizacji języka, który odbywa się głównie za pośrednictwem systemu edukacyjnego. Zgodnie z ustawą o autonomii, w dzisiejszym Kraju Basków, będącym jedną z 17 wspólnot autonomicznych, zarówno baskijski, jak

$4 \quad 33,3$ \% używa częściej katalońskiego niż hiszpańskiego, 17,1\% używa w równym stopniu obu języków, 39,6\% posługuje się częściej kastylijskim niż katalońskim. Wg Institut d’Estadística de Catalunya Enquesta d'usos lingüístics de la població, https://www.idescat.cat/cat/idescat/publicacions/cataleg/pdfdocs/eulp2013.pdf [15.02.2018]

5 VI Encuesta Sociolingüistica. Comunidad Autónoma de Euskadi: http://www.euskara. euskadi.eus/contenidos/informacion/argitalpenak/es_6092/adjuntos/VI\%20_INK_SOZLG_EAE_ Presentacion_publica_20161014.pdf [25.02.2018]

6 Wg Baskijskiego Instytutu Statystycznego (Instituto Vasco de Estadística) w 2017 roku we Wspólnocie Autonomicznej mieszkało 2175819 osób. Zob. http://www.eustat.eus/elementos/ ele0011400/Poblacion_de_la_CA_de_Euskadi_por_ano_de_nacimiento_segun_el_territorio_historico_y_el_sexo/tbl0011424_c.html [4.04.2018] 
i hiszpański posiadają status języków oficjalnych. Jednak obecność języka hiszpańskiego jest zdecydowanie dominująca, biorąc pod uwagę dwujęzyczność prawie całej populacji baskijskojęzycznej i masową obecność języka hiszpańskiego w środkach masowego przekazu (Aranga, Amezaga, Azpillaga 2009).

Przyjrzyjmy się jeszcze raz Katalonii. Według danych ankiety „Użycie i znajomość katalońskiego" z 2013 r. Katalońskiego Instytutu Statystyki ${ }^{7}$ w prywatnych sytuacjach komunikacyjnych użycie języka katalońskiego jest opcją większościową tylko w przypadku studentów (42,9\%); kastylijski znajduje się na drugim miejscu $(30,8 \%)$, a wykorzystanie w równym stopniu języku katalońskiego i hiszpańskiego deklaruje $17,4 \%$ ankietowanych. Przy sporządzaniu notatek osobistych 55,7\% wybiera język hiszpański, 27,8\% preferuje język kataloński, a 7,3\% używa obu języków jednakowo. Z przyjaciółmi także najczęściej używa się języka kastylijskiego $(43,8 \%)$, natomiast język kataloński używany jest przez 30,9\% populacji Katalonii. 15,7\% ankietowanych używa w kontaktach z przyjaciółmi zarówno języka katalońskiego, jak i hiszpańskiego. Jeśli chodzi o relacje z sąsiadami, prawie połowa populacji Katalonii posługuje się językiem hiszpańskim (49\%), w porównaniu do 31,9\% ankietowanych używających języka katalońskiego. Komunikacja z lokalną administracją (47,9\%) oraz z Generalitat de Catalunya (46,2\%), odbywa się po katalońsku. Natomiast kastylijski preferowany jest w kontaktach z bankami (43,3\%), z lekarzem $(46,3 \%)$, w centrach handlowych $(48,7 \%)$ i małych sklepach (44\%), oraz w kontaktach z administracją państwową (47,5\%).

\subsection{Interferencje językowe (code-mixing): kastylijski i kataloński}

Z jednej strony, język kastylijski używany na Półwyspie Iberyjskim ma swoje odmiany regionalne, które w dwujęzycznych wspólnotach autonomicznych wynikają przynajmniej częściowo - z kontaktu $z$ językiem regionalnym. $Z$ drugiej strony języki regionalne wykazują cechy wynikające z koegzystencji zjęzykiem kastylijskim. Dlatego też, mimo tego, że mówi się o jednym języku, tak naprawdę chodzi o jego w pewnym stopniu zhybrydyzowaną odmianę (zob. Gugenberger 2008: 32).

Warto wspomnieć o tym, że wszystkie kody językowe dziś uważane za języki zostały utworzone w procesie przenikania się elementów różnych języków (łaciny, celtyckiego, języków germańskich, arabskiego itd.) w procesach hybrydyzacji językowej, dzięki którym skrystalizowały się poszczególne języki romańskie. W romańskim continuum językowym podziały wynikają w dużej mierze z kryteriów politycznych (Porcar Miralles 2002: 190). Granice językowe nigdy nie są ostrymi granicami, te wszakże są tworami człowieka. Poza tym, w Hiszpanii nie ma absolutnej równoważności między podziałami polityczno-administracyjnymi a językowymi.

Ponadto należy zauważyć, że nie tylko nowa (po śmierci Franco w 1975 r.) sytuacja polityczna, ale także czynnik społeczny odgrywa ważną rolę w każdej zmianie

7 Ús i coneixment del català (2013): http://www.idescat.cat/cat/idescat/publicacions/cataleg/pdfdocs/dossier17.pdf [4.04.2018] 
postrzegania języka i polityki językowej. Można powiedzieć, że Hiszpania łączy dwie sprzeczne zasady - kilka narodowości istnieje w ramach jednego narodu hiszpańskiego. Konstytucja hiszpańska z 1978 r., podobnie jak dokumenty legislacyjne wielu krajów europejskich, nie używa terminu „mniejszość” do identyfikacji osób używających języka innego niż język oficjalny.

Zagadnienie interferencji odnosi się zarówno do cech indywidualnych związanych z akwizycją, percepcją oraz uzusem języków, jak i do szeregu zagadnień z dziedziny socjo- i psycholingwistyki. Kolejny raz przyjrzyjmy się Katalonii. Język kastylijski używany w Katalonii przejawia pewne cechy charakterystyczne, które odzwierciedlają wieloletni kontakt między językiem hiszpańskim i katalońskim. Jeśli uznamy kastylijski za język przyjmujący, to na poziomie gramatycznym można np. wyróżnić przykład często używanej peryfrazy haber de + bezokolicznik, która jest preferowana w kastylijskim używanym na terytorium Katalonii wobec bardziej typowej dla hiszpańskiego formy tener que + bezokolicznik. Można także wymienić zapożyczenia, które pojawiają się w języku hiszpańskim używanym w Katalonii, takie jak czasowniki caldre lub enchegar. Słowa, które już istnieją w języku hiszpańskim, ale mają inne znaczenie niż znaczenie w Katalonii, nazywane są katalonizmami i stanowią przykłady przesunięcia semantycznego. Do tej grupy należą słowa takie jak paleta ('murarz'), plegar ('kończyć'), gastar ('używać'). Należy także wspomnieć o kalkach, takich trobar a faltar wobec hiszpańskiego echar de menos 'tęsknić' (Blas Arroyo 2005).

Interferencja fonetyczna na terytorium katalońskojęzycznym występuje w języku przyjmującym, kastylijskim, pod wpływem dźwięków języka katalońskiego. Na przykład nieakcentowane samogłoski [e] i [a] podlegają redukcji do samogłoski środkowej. Typowa jest także wymowa nieakcentowanego [o] jako [u] (redukcja i zamknięcie samogłoski).

Interferencja może powodować błędy ortograficzne. Kataloński i hiszpański mają podobne systemy ortograficzne, jednak niektóre osoby dwujęzyczne mogą popełniać błędy takie jak pisownia hiszpańskiego cambio ('zmiana') jako *canvio, pod wpływem katalońskiego canvi. Można zaobserwować wyraźny wpływ języka katalońskiego na użycie przyimków $a$ oraz en w języku hiszpańskim, w przypadkach takich jak *Estoy a casa zamiast Estoy en casa ('Jestem w domu') (Blas Arroyo 2005).

\section{Podstawy prawne obecnej sytuacji językowej w Hiszpanii}

\subsection{Zarys historyczny}

Wielojęzyczność Hiszpanii jest faktem i przyczyny tej sytuacji mają swoje korzenie w historii Półwyspu Iberyjskiego. Obok jedynego języka sprzed podboju Półwyspu przez Imperium Rzymskie, tj. baskijskiego, na terytorium dzisiejszej Hiszpanii rozwijało się kilka odmian łaciny ludowej, które przez stulecia stały się oddzielnymi językami 
z bogatszą lub mniej pokaźną tradycją tekstów pisanych. Ze względów historycznopolitycznych i dynastycznych, kastylijski został ustanowiony dominującym językiem Hiszpanii. Ta przewaga kastylijskiego wynika także z okresowych zakazów używania innych języków ${ }^{8}$. Ponieważ w obecnym modelu ustrojowym kwestia językowa jest ściśle związana z decentralizacją państwa, zaczniemy od analizy projektu prawnego z XIX wieku.

Pierwsza Republika próbowała wprowadzić model federalny opisany w tekście konstytucji z 1873/74 roku. Chociaż w projekcie tym nie wspomina się o językach, interesujące jest to, jak rozwija się idea Hiszpanii federalnej. Projekt mówi o 17 regionach Hiszpanii (zbiegiem okoliczności jest to liczba aktualna i dzisiaj). Wspomniana konstytucja nigdy jednak nie weszła w życie i federaliści musieli czekać do Drugiej Republiki, kiedy zatwierdzono konstytucję z 1931 roku. W jej rozdziale wstępnym (titulo preliminar), artykuł 4 odnosi się po raz pierwszy w historii hiszpańskich konstytucji do zagadnienia językowego:

\begin{abstract}
Kastylijski jest oficjalnym językiem Republiki.
Wszyscy obywatele Hiszpanii mają obowiązek go znać i prawo do korzystania z niego, bez uszczerbku dla praw, które prawo państwa uznaje dla języków prowincji lub regionów.

Z wyjątkiem przypadków przewidzianych w przepisach szczególnych, nikt nie może być zobowiązany do znajomości lub używania jakiegokolwiek języka regionalnego ${ }^{9}$.
\end{abstract}

Jak widać, językowi kastylijskiemu przyznano rolę dominującą w społeczeństwie, opartą o bardzo silny status prawny (Doppelbauer 2008: 23), ale przynajmniej uznano istnienie innych języków, które będą miały prawo do funkcjonowania na poziomie regionalnym. Zgodnie z artykułem 8 omawianej Konstytucji, wg którego prowincje i regiony mogły ustanowić pewną formę autonomii, Katalonia wprowadza politykę autonomiczną wraz ze swoim językiem, katalońskim.

W wyniku zamachu stanu z 1936 roku i wojny domowej w Hiszpanii, Konstytucja Drugiej Republiki została zniesiona przez reżim Franco. Na mocy Dekretu nr 138 z 1936 roku $^{10}$ generał Francisco Franco Bahamonde przejął całą władzę w nowym państwie, w którym podczas 40 lat istnienia kastylijski był jedynym językiem oficjalnym, a pozostałe języki używane na terytorium Hiszpanii były zakazane i do pewnego stopnia prześladowane.

Reżim Franco podkreślił język jako symbol jednorodności i jedności, aby narzucić poczucie lojalności i patriotyzmu (González Antón 1997: 613). Echo takiego myślenia, tj. postrzegania społeczeństwa poprzez pryzmat jednego, „narodowego” języka wybrzmiewa i dzisiaj, np. w debacie dotyczącej imigrantów z Maroka wobec imigran-

8 Mam na myśli okres dyktatury frankistowskiej, zob. El País (2012).

9 Tłumaczenie MPJ na podstawie tekstu dostępnego na stronie: http://www1.icsi.berkeley. edu/ chema/republica/constitucion.html [15.02.2018]

10 Decreto 138/1936, de 29 de septiembre: http://constitucionparatodos.com/wp-content/ uploads/2017/08/9.-Leyes-fundamentales-franquistas.pdf [25.03.2018] 
tów z krajów hiszpańskojęzycznych ${ }^{11}$. Słynna fraza z czasów frankistowskich ;Habla cristiano! ('Mów po chrześcijańsku!', tj. po kastylijsku) jest wyraźnym przykładem tego, w jaki sposób reżim propagował jedność języka kastylijskiego (,chrześcijańskiego") a chrześcijaństwem (religią), budując własną koncepcję jedności, wykluczającą jakąkolwiek różnorodność. Hiszpania miała być „,społeczeństwem bez różnorodności”, jednakowym i spójnym i, co ważniejsze, dyskryminującym z mocy prawa jakąkolwiek formę wyrażania różnorodności (inny język, inna religia itd.).

\subsection{Konstytucja Królestwa Hiszpanii z 27 grudnia 1978 r.}

Po czterdziestu latach dyktatury Hiszpania przekształciła się w stabilną demokrację. Unikatowym rozwiązaniem stosowanym przez obecną Konstytucję jest powiązanie kwestii mniejszości (językowych) z kwestią organizacji administracji terytorialnej i decentralizacji władzy. Niemożliwe jest zrozumienie hiszpańskiej rzeczywistości językowej bez uwzględnienia czynnika regionalnego i odwrotnie. Na mocy hiszpańskiego modelu Estado de las Autonomías władzę polityczną dzieli się między centralne organy państwa i rządy autonomiczne, posiadające znaczny stopień samodzielności w różnych dziedzinach. System ten jest podobny do struktury federalnej, ale najbardziej odpowiada zdecentralizowanemu modelowi państwa złożonego z regionów. Od rozwiązania federalnego różni się głównie tym, że kompetencje każdego regionu, tj. wspólnoty autonomicznej (comunidad autónoma) są różne. Konstytucja hiszpańska nie określa zakresu autonomii dla wspólnot narodowych, ale zapewnia im możliwość samodzielnego określenia granic i treści ich autonomii, oczywiście w ramach Konstytucji. Zgodnie z art. 143-144 graniczące z prowincjami o wspólnych cechach historycznych, kulturowych i ekonomicznych terytoria wyspiarskie i prowincje o historycznym statusie regionalnym mogą tworzyć wspólnoty samorządowe. Ponadto, w interesie narodowym, hiszpański parlament (Kortezy, Cortes Generales) może przyznać autonomię tym jednostkom terytorialnym, które nie mogą spełnić powyższych kryteriów. Konstytucja ustanawia dwie procedury służące osiągnięciu autonomii. Warunkiem stworzenia autonomicznej wspólnoty w obu przypadkach jest statut zatwierdzony przez Kortezy. Technicznie Konstytucja uznała regiony, zamiast je ustanowić, uznając w ten sposób ich prawo do autonomii. Niemniej jednak zdecydowanie podkreśla się jedność państwa

11 W niektórych przypadkach przybycie imigrantów wzmacnia tradycyjne procesy asymilacyjne na szczeblu krajowym, ponieważ imigranci już mówią oficjalnym językiem dominującym. Dzieje się tak w przypadku imigrantów z Ameryki Łacińskiej w Hiszpanii, którzy osiedlają się w dwujęzycznych społecznościach. Ich obecność niewątpliwie zwiększa wagę języka kastylijskiego i może być postrzegana jako zagrożenie dla sytuacji języka mniejszości (języka regionalnego). Niemniej jednak, imigracja w Hiszpanii jest bardzo zróżnicowana pod względem krajów pochodzenia przybyszy. Najliczniejsze grupy imigrantów (z wyłączeniem obywateli UE) to obywatele Maroka, Rumunii, Ekwadoru i Kolumbii. Dane globalne pozwalają dostrzec znaczenie hiszpańskiej przeszłości kolonialnej w wyborze niektórych przepływów imigracyjnych, ale także wskazują na nowe wpływy z krajów o niewielkim historycznym związku z Hiszpanią (zob. Ruiz Vieytez 2007: 6). 
hiszpańskiego, odmawiając jakiegokolwiek prawa do samostanowienia w tradycyjnym znaczeniu suwerenności (Ehrlich 2008: 306-309):

Konstytucja opiera się na nierozerwalnej jedności Narodu hiszpańskiego, wspólnej i niepodzielnej ojczyzny wszystkich Hiszpanów, a także uznaje i zapewnia prawo do autonomii stanowiących go narodowości i regionów oraz solidarność między wszystkimi ${ }^{12}$.

Konstytucja Hiszpanii z 1978 r. odnosi się do kwestii językowej w kilku punktach. Po raz pierwszy odniesiono się w niej do wielojęzycznej rzeczywistości państwa (Vernet i Punset 2007: 23). Główne zasady dotyczące języka znajdują się na samym początku tekstu konstytucyjnego. Po preambule, w której deklarowana jest wola państwa hiszpańskiego do ,[...] ochrony wszystkich Hiszpanów w zakresie realizacji praw człowieka oraz pielęgnowania ich kultur i tradycji, języków i instytucji”, prawa i obowiązki związane z wielojęzycznym dziedzictwem Hiszpanii określa artykuł 3:

1. Kastylijski jest hiszpańskim urzędowym językiem państwa. Wszyscy Hiszpanie mają obowiązek go znać i prawo posługiwać się nim.

2. Pozostałe języki hiszpańskie są również językami urzędowymi w odpowiednich wspólnotach autonomicznych, zgodnie $\mathrm{z}$ ich statutami.

3. Bogactwo różnych odmian językowych Hiszpanii jest dziedzictwem kulturowym, które jest przedmiotem szczególnego poszanowania i szczególnej ochrony.

Akapit pierwszy powyższego artykułu wprowadza zasadnicze rozróżnienie między językiem kastylijskim a językami regionalnymi: Hiszpanie mają obowiązek znać tylko kastylijski, tymczasem nie nakłada się takiego obowiązku w odniesieniu do innych języków urzędowych. W rzeczywistości Trybunał Konstytucyjny w swoim wyroku z 23 grudnia 1994 r. ${ }^{13}$ orzekł, że art. 3 zakazuje nakładania obowiązku znajomości jakiegokolwiek języka innego niż kastylijski. Poprzez drugi akapit art. 3 państwo ustanawia system współdziałania dwujęzycznych regionów. Co więcej, praktycznie deleguje prawo do rozporządzania (w niektórych aspektach) kwestią językową - oczywiście w ramach Konstytucji - regionom autonomicznym. Przy wyliczaniu kompetencji, które mogą przyjmować regiony autonomiczne, wyraźnie wskazano promocję kultury i badań oraz nauczanie języka wspólnoty autonomicznej (artykuł 148.1.17):

1. Wspólnoty autonomiczne mogą przejąć kompetencje w następujących kwestiach: $[\ldots]$

17) wspierania rozwoju kultury, badań naukowych oraz, w określonych wypadkach, nauczania języka wspólnoty autonomicznej,

12 Wszystkie thumaczenia na język polski tekstu Konstytucji Hiszpanii z 1978 r. podaję za tłumaczeniem Tadeusza Mołdawy, dostępnym na stronie biblioteki Sejmu RP: http://biblioteka. sejm.gov.pl/wp-content/uploads/2015/10/Hiszpania_pol_300612.pdf [15.02.2018]

13 SENTENCIA 337/1994, de 23 de diciembre, (BOE núm. 19, de 23 de enero de 1995): http://hj.tribunalconstitucional.es/es/Resolucion/Show/2854\#complete_resolucion\&completa [5.03.2018] 
Jednak zgodnie z tym sformułowaniem Konstytucja jedynie nakłada obowiązek na władze, ale nie zapewnia członkom mniejszości językowych podstawowego prawa w odniesieniu do języka, na które mogliby się powoływać przed sądami. Wreszcie akapit trzeci art. 3 zawiera zasadę przewodnią dla władz publicznych, która, zgodnie z preambułą, wskazuje na potrzebę tworzenia pozytywnych technik ochrony różnych przejawów bogactwa językowego Hiszpanii.

Porządek językowy ustanowiony przez Konstytucję ma charakter mieszany: nie jest to ani porządek całkowicie terytorialny, ponieważ wyklucza priorytet języka terytorialnego (z wyjątkiem, oczywiście, terytoriów hiszpańskojęzycznych), ani całkowicie osobisty, ponieważ nie rozszerza wykonywania indywidualnych praw językowych - wynikających z posiadania obywatelstwa dwu- lub wielojęzycznej wspólnoty autonomicznej - na wszystkich obywateli, którzy pragną korzystać z nich niezależnie od miejsca zamieszkania (Nagy 2012: 191).

Konstytucja z 1978 roku jest kontynuacją ducha konstytucji z 1931 roku, w tym sensie, że utwierdza powszechny i niepodważalny status oficjalny języka hiszpańskiego, zwanego także w tym tekście kastylijskim. Ponadto uznano oficjalny status pozostałych języków Hiszpanii w ich wspólnotach autonomicznych i zagwarantowano ochronę ich dziedzictwa kulturowego. W ten sposób pozostawiono otwarte drzwi dla prawodawstwa językowego wspólnot autonomicznych poprzez odpowiednie statuty, które odnosiłyby się do obecności języków regionalnych w edukacji i różnych sferach życia publicznego. Można zatem powiedzieć, że całość aktów prawnych, składająca się z Konstytucji z 1978 r. oraz ze statutów wspólnot autonomicznych, ma wybitnie innowacyjny charakter, o wiele bardziej niż odpowiednie ustawodawstwo z tego zakresu w Niemczech, Francji lub Włoszech (Moreno-Fernández 2004: 21). Rozwiązania konstytucyjne niewątpliwie doprowadziły do wzrostu wykorzystania i społecznego prestiżu języków używanych w Katalonii, Galicji i Kraju Basków, zarówno na terytorium Hiszpanii, jak i poza nim.

Jak zauważa Jackiewicz (2013: 293):

Ustrojodawca, uwzględniając zróżnicowaną legitymację różnych ambicji poszczególnych regionów, przewidział dwie metody kreowania wspólnot autonomicznych oraz związany z tym zróżnicowany poziom kompetencji i odpowiedzialności, a tym samym dwie kategorie wspólnot autonomicznych. Kraj Basków, Katalonia i Galicja, nazywane regionami historycznymi, uzyskały prawo do uzyskania konstytucyjnej autonomii w drodze uproszczonego i przyspieszonego procesu.

\subsection{Ustawy regionalne dotyczące polityki językowej}

Kwestie językowe poruszone w Konstytucji z 1978 r. oraz poszczególne regionalne regulacje prawne otworzyły drogę do przygotowania regionalnych przepisów dotyczących języka ${ }^{14}$. Rozwój ustawodawstwa regionalnego nie przeszkodził jednak

14 M. in. w kraju Basków (ustawa 10/1982), Galicji (akt 3/1983), Wspólnocie walenckiej (ustawa 1/1983), Katalonii (ustawa z 1/1998), Nawarze (ustawa 18/1998), Asturii (ustawa 1/1998) i Aragonii (ustawa 3/2013). 
rządowi centralnemu w wykonywaniu jego uprawnień, tj. w uregulowaniu, w jaki sposób współoficjalny status języków regionalnych funkcjonuje w takich praktycznych dziedzinach, jak edukacja i szkoły, dostęp do usług publicznych, administracja lokalna, sądy, służba zdrowia i znaki drogowe.

Przepisy prawne z wyżej wspomnianych dziedzin i ich wprowadzanie w życie spowodowały liczne spory, które najpierw rozstrzygano przed sądami powszechnymi, a następnie przed Trybunałem Konstytucyjnym, który w swoim orzecznictwie powoli ustanawiał ramy dla współistnienia dwóch języków oficjalnych. Odpowiednie orzecznictwo konstytucyjne to wyroki 82, 83 i 84 z 26 czerwca 1986 r. $^{15}$, wydane w odpowiedzi na projekty ustaw przedłożonych rządowi centralnemu w sprawie normalizacji języka baskijskiego, katalońskiego i galicyjskiego. Zgodnie z tymi wyrokami kastylijski, jako oficjalny język całego kraju, nie może być postrzegany jako rywal języków regionalnych, zważywszy, że zarówno rządy regionalne, jak i rząd centralny są w równym stopniu zobowiązane do przestrzegania i ochrony poszczególnych języków Hiszpanii ${ }^{16}$.

\subsection{Kazus Katalonii}

Od ponad 40 lat ekspansja języka katalońskiego jest bardzo udana. Jest on rozumiany przez $95 \%$ i używany przez ponad $80 \%$ populacji Katalonii. Na początku tzw. okresu przejściowego (tzw. Transición, okresu po śmierci Franco do skonsolidowania się instytucji demokratycznych) obawiano się o jego dalszy rozwój. Niemniej jednak, dzięki $\mathrm{m}$ in. triumfowi ustroju demokratycznego, zwieńczonego uchwaleniem Konstytucji 1978 r., która - jak wspomniano wcześniej - ustanawia i celebruje pluralizm jako wspólne dziedzictwo wszystkich Hiszpanów, język kataloński mógł intensywnie rozwijać się i stać się jednym z wyznaczników katalońskości. Żywotność języka katalońskiego wynika zatem z udzielonego mu wsparcia. Dlatego, wbrew temu, co mówią zwolennicy popierający niepodległość Katalonii, nie jest to język sierocy ani bez państwa. Jego witalność wynika z zaangażowania użytkowników oraz uznania i wsparcia państwa hiszpańskiego (zob. El País 2018).

Zgodnie z art. 33 ust. 1 Statutu Autonomii z 2006 r. ${ }^{17}$ obywatele Katalonii mają prawo do wyboru języka, w którym chcą się porozumiewać z organami władzy, a prawo

15 SENTENCIA 82/1986, de 26 de junio, (BOE núm. 159, de 04 de julio de 1986) http:// hj.tribunalconstitucional.es/es/Resolucion/Show/645 [5.03.2018]

SENTENCIA 83/1986, de 26 de junio, (BOE núm. 159, de 04 de julio de 1986) http://hj.tribunalconstitucional.es/es/Resolucion/Show/646 [5.03.2018]

SENTENCIA 84/1986, de 26 de junio, (BOE núm. 159, de 04 de julio de 1986) http://hj.tribunalconstitucional.es/es/Resolucion/Show/647 [5.03.2018]

16 zob. informacje dot. ustawodawstwa Hiszpanii z zakresu języków opublikowane na stronie Compendium Cultural Policies and Trends in Europe Rady Europy: http://www.culturalpolicies. net/web/spain.php?aid=519 [15.02.2017]

17 Estatuto de Autonomía de Cataluña: https://www.parlament.cat/document/cataleg/48146. pdf [4.04.2018] 
to jest wiążące dla instytucji, organizacji i administracji publicznej, w tym administracji Hiszpanii w Katalonii, i ogólnie, dla organizacji prywatnych, gdy świadczą one usługi publiczne. Chociaż art. 3 ust. 2 Konstytucji Hiszpanii stwierdza, że języki urzędowe inne niż kastylijski są również urzędowe, to ich oficjalny status jest ustanowiony tylko na terytorium wspólnot autonomicznych, które zakwalifikowały je jako takie w swoich statutach. To uznanie oficjalnego statusu reszty języków hiszpańskich ograniczające się do terytoriów wspólnot autonomicznych zmniejsza ich skuteczność i może prowadzić do wniosku, że Konstytucja sama ustanowiła hierarchię między kastylijskim i wszystkimi pozostałymi językami, ponieważ obowiązek ich znajomości jest tylko określony dla pierwszego, tj. kastylijskiego. W innych krajach, takich jak Kanada czy Finlandia, języki urzędowe są oficjalne w całym państwie, co zapobiega występowaniu zażaleń wśród obywateli tego samego państwa, którzy posługują się różnymi językami, ponieważ oba języki mają identyczny status prawny. Artykuły 3.3 i 20 Konstytucji Hiszpanii, mające na celu zagwarantowanie szczególnego poszanowania i ochrony różnych języków państwa oraz promowanie pluralizmu językowego w środkach masowego przekazu, muszą zostać sprecyzowane. Brak precyzji i pojawiająca się możliwość różnych interpretacji generuje negatywny klimat, przez który wraz z upływem czasu gromadzą się skargi i zażalenia obywateli Hiszpanii, ze szkodą dla ochrony wymaganej dla wszystkich języków państwa.

Ponadto wraz z orzeczeniem 31/2010 Trybunału Konstytucyjnego Królestwa Hiszpanii $^{18}$, które uznaje kastylijski wraz z katalońskim językami nauczania w Katalonii, rozpoczęła się legislacyjna bitwa wokół modelu językowego w katalońskich szkołach. Wspomniane orzeczenie uznaje za niekonstytucyjne niektóre sformułowania dot. nauczania języka katalońskiego. Kością niezgody pozostaje brak możliwości wyboru preferowanego języka nauczania w szkołach katalońskich i założenie, że tym językiem jest język kataloński. Kwestia zakresu wykorzystania języka kastylijskiego w katalońskim systemie edukacji pozostaje otwarta. Rząd centralny obiecał, że zagwarantuje prawo rodziców do wyboru języka kastylijskiego jako języka kształcenia w Katalonii i poszukuje wszelkiego rodzaju formuł prawnych, aby urzeczywistnić tę obietnicę. Niemniej jednak 4 kwietnia 2018 roku uznał ${ }^{19}$, że nie może stanąć w sprzeczności z katalońskim prawem edukacyjnym i zrezygnował z wprowadzenia na kartach rozsyłanych rodzicom, których dzieci rozpoczynają edukację, pola, którego zaznaczenie wskazywałoby na wybór języka kastylijskiego jako głównego języka procesu kształcenia (zob. El Mundo 2018).

W przypadku sektora kulturalnego ustawodawstwo katalońskie (ustawa 1/1998 o polityce językowej) określa na przykład kwoty językowe dla licencjonowanych programów radiowych i telewizyjnych. W celu promocji katalońskiej muzyki oraz przekazu radiowego i telewizyjnego, środki masowego przekazu muszą zagwarantować, że programy muzyczne zapewnią odpowiednią ilość czasu (co najmniej 25\% emisji) utworom wykonywanym przez artystów katalońskich.

18 SENTENCIA 31/2010, de 28 de junio, (BOE núm. 172, de 16 de julio de 2010) http:// hj.tribunalconstitucional.es/es/Resolucion/Show/6670 [5.03.2018]

19 RESOLUCIÓN ENS/603/2018 z dnia 27 marca 2018 r.: http://estaticos.elmundo.es/documentos/2018/04/04/resolucion_casilla.pdf [5.04.2018] 


\section{Uwagi końcowe}

Po czterech dekadach demokratycznego i konstytucyjnego rozwoju państwo hiszpańskie zbudowane wg modelu Estado de las Autonomías jest niemal jednogłośnie uznawane za innowacyjne i reagujące na żądania mniejszości, stanowiąc przykład udanego funkcjonowania społeczeństwa wielonarodowościowego w jednym państwie.

Niemniej jednak wydaje się zbyt optymistyczne, aby powiedzieć, że „,walka o status języków mniejszościowych została wygrana", ponieważ polityka regionalna nadal dominuje w hiszpańskiej debacie konstytucyjnej i zyskuje coraz większe znaczenie w agendzie Unii Europejskiej (zob. Nágy 2012: 13). Faktyczny udział wspólnot autonomicznych we władzy ustawodawczej pozostaje nierozwiązany.

Konieczne jest dalsze poszukiwane optymalnych rozwiązań zmierzających do znalezienia równowagi w zakresie ochrony zapewnianej tradycyjnym językom mniejszości (oraz innych grup etnicznych) od dawna zamieszkujących terytorium Hiszpanii. Ponadto, wcześniej lub później, będzie musiało zostać rozważone sprecyzowanie zakresu funkcjonowania języków innych niż kastylijski na terytorium Królestwa Hiszpanii w zakresie budowy i ewolucji polityki wielokulturowej, szczególnie w sytuacji rosnącej imigracji do Królestwa Hiszpanii.

\section{Bibliografia}

Aranga, Edorta \& Amezaga, Josu \& Azpillaga, Patxi 2009: Los medios de comunicación en euskara. Universidad del País Vasco, Servicio Editorial. https://www.ehu.eus/documents/2660428/2748262/ Media_en_euskara.pdf [4.04.2018]

Blas Arroyo, José Luis 2005: El español actual en las comunidades del ámbito lingüístico catalán. W: Cano Aguilar, Rafael (red.): Historia de la lengua española. Wyd. 2. Barcelona: Editorial Ariel S.A.

Doppelbauer, Max 2008: La Constitución y las lenguas españolas. W: Doppelbauer, Max i Cichon, Peter (red.): La España multilingüe: Lenguas y políticas lingüísticas de España. Wien: Praesens Verlag.

El Mundo 2018: El Gobierno renuncia a aplicar el 155 para garantizar el castellano en la preinscripción escolar en Cataluña. http://www.elmundo.es/cataluna/2018/04/04/5ac4971a468aeb b0078b45ba.html [4.04.2018]

El País 2012: Españolizar ya lo hizo Franco... y fracasó. 14.10.2012: https://elpais.com/ sociedad/2012/10/14/vidayartes/1350243756_004204.html [28.02.2018]

El País 2018: Lengua de España. El éxito del catalán es el de la democracia y el autogobierno. 25.02.2018: https://elpais.com/elpais/2018/02/24/opinion/1519488490_264686.html [28.02.2018]

Ehrlich, Charles 2000: Ethno-cultural Minorities and Federal Constitutionalism: Is Spain Instructive? Southern Illinois University Law Journal 1999-2000/24, 302-316.

González Antón, Luis 1997: España y las Españas. Madrid: Alianza.

Gugenberger, Eva 2008: El castellano y las lenguas regionales en España: Bilingüismo e hibridación. W: Doppelbauer, Max i Cichon, Peter (red.): La España multilingüe: Lenguas y politicas lingüísticas de España. Wien: Praesens Verlag. 
Jackiewicz, Andrzej 2013: Uwagi na temat kontekstu historycznego regionalizmu baskijskiego. W: Grzybowski, Marian i Kuca, Jerzy (red.): Ustroje. Historia i współczesność. Polska-Europa - Ameryka Łacińska. Kraków: Wydawnictwo Uniwersytetu Jagiellońskiego.

Moreno-Fernández, Franscisco 2004: Planificación lingüística en España, urbinavolant.com/archivos/ curso1011/Term/lecttema08.doc [15.02.2018]

Nagy, Noémi 2012: Linguistic Diversity and Language Rights in Spain. In: Essays of Faculty of Law University of Pécs Yearbook of 2012. Pécs: University of Pécs, Faculty of Law.

Porcar Miralles, Margarita 2002: Algunas consideraciones históricas sobre el contacto de las lenguas española y catalane. W: Blas Arroyo et al. (red.): Estudios sobre lengua y sociedad. Castelló: Publicaciones de la Universitat Jaume I.

Ruiz Vieytez, Eduardo J. 2007: New minorities and linguistic diversity: Some reflections from the Spanish and Basque perspectives. Journal on Ethnopolitics and Minority issues in Europe, 2, www.ecmi.de/fileadmin/downloads/.../2007/2-2007-Vieytez.pdf [15.02.2018]

Thomason, Sarah Grey \& Kaufman, Terrence 1988: Language Contact, Creolization, and Genetic Linguistics. Berkley/Los Angeles/London: University of California Press.

Vernet, Jaume \& Punset, Ramón 2007: Lenguas y Constitución. Madrid: Iustel. 